\title{
The HrpX/HrpY Two-Component System Activates hrpS Expression, the First Step in the Regulatory Cascade Controlling the Hrp Regulon in Pantoea stewartii subsp. stewartii
}

\author{
Massimo Merighi, Doris R. Majerczak, Elizabeth H. Stover, and David L. Coplin \\ Department of Plant Pathology and the Plant Molecular Biology/Biotechnology Program, The Ohio State University, \\ 2021 Coffey Road, Columbus, Ohio 43210-1087, U.S.A.
}

Submitted 23 July 2002. Accepted 18 November 2002.

\begin{abstract}
A regulatory cascade activating $h r p / h r c$ type III secretion and effector genes was delineated in Pantoea stewartii subsp. stewartii, a bacterial pathogen of corn. Four hrp regulatory genes were characterized: $h r p X$ and $h r p Y$ encode the sensor kinase and response regulator, respectively, of a two-component signal transduction system; hrpS encodes an NtrClike transcriptional enhancer; and $h r p L$ encodes an alternative sigma factor. Epistasis analysis, expression studies using gene fusions, and genetic reconstruction of each step in Escherichia coli were used to delineate the following pathway: HrpY activates $h r p S$ and also positively autoregulates the $h r p X Y$ operon. In turn, HrpS is required for full activation of the $\sigma^{54}$-dependent $h r p L$ promoter. Finally, HrpL controls expression of all known $h r p$ and wts genes. In vitro, $h r p S$ and all downstream $h r p$ genes were regulated by $\mathbf{p H}$ and salt concentration. Mutants with in-frame deletions in $h r p X$ were still partially virulent on corn but were unable to sense the chemical or metabolic signals that induce $h r p$ genes in vitro. Site-directed mutagenesis of HrpY indicated that aspartate $\mathbf{5 7}$ is the probable phosphorylation site and that it is needed for activity. These findings suggest that both HrpX and an alternate mechanism are involved in the activation of HrpY in planta.
\end{abstract}

Additional keywords: Erwinia stewartii, PAS domains.

Pantoea stewartii subsp. stewartii (synon. Erwinia stewartii) causes Stewart's bacterial wilt and leaf blight of sweet corn and maize (Zea mays L.). Stewart's wilt is the most serious bacterial disease of sweet corn in the north-central and eastern United States. The pathogen is transmitted by the corn beetle (Chaetocnema pulicaria) through feeding wounds (Claflin 1999). Bacteria grow in the xylem vessels of the host plant causing wilt and in the intercellular spaces of the leaves causing "water-soaked" lesions. The primary virulence factor responsible for wilting is the extracellular polysaccharide (EPS) (Dolph

Corresponding author: D. L. Coplin; Telephone: 614-292-1375; Fax: 614-292-4455; E-mail: coplin.3@ osu.edu.

Current address of E. H. Stover: Harvard Medical School, Harvard-MIT Division of Health Sciences and Technology, 260 Longwood Avenue, Room 213, Boston, MA 02115, U.S.A.

Nucleotide sequence data reported for $h r p L, h r p X Y$, and $h r p S$ are available in the GenBank database under accession number AF282857. et al. 1988), and the genes required for its production and regulation have been characterized (Coplin and Majerczak 1990; Dolph et al. 1988; Poetter and Coplin 1991; Torres-Cabassa et al. 1987). Water-soaking (Wts) is the result of cell membrane damage and the accumulation of fluids in the leaf tissue.

A cluster of hrp genes (Alfano and Collmer 1997) is required by many gram-negative plant-pathogenic bacteria for elicitation of the hypersensitive response (HR) (Klement 1982) in nonhost plants and for pathogenicity in a compatible host. hrp genes encode a type III secretion system that is conserved among plant and animal bacterial pathogens (Galan and Collmer 1999). They also encode several regulatory proteins and the secreted effector proteins that determine interactions with susceptible and resistant hosts. Pantoea stewartii has a typical $h r p$ cluster that spans over $28 \mathrm{~kb}$ and that is required for HR elicitation in tobacco and disease in corn (Ahmad et al. 2001; Coplin et al. 1986, 1992; Frederick et al. 2001). In contrast to more necrogenic pathogens such as Pseudomonas syringae and Erwinia amylovora, Pantoea stewartii is only able to elicit a HR in tobacco leaves when the bacteria are pregrown in a Hrp-inducing minimal medium or when $h r p S$ is constitutively expressed (Ahmad et al. 2001). Thus, unlike sweet corn and maize, tobacco does not provide all of the signals necessary to induce hrp gene expression in this species.

In gram-negative plant pathogenic bacteria, there are two lineages of $h r p$ genes that differ significantly in their mode of regulation (Alfano and Collmer 1997). In general, expression of hrp genes is environmentally regulated. Both plant factors (Aldon et al. 2000; Schulte and Bonas 1992) and chemi$\mathrm{cal} /$ metabolic stimuli mimicking the plant apoplast (Rahme et al. 1992; Wei et al. 1992; Xiao et al. 1992) have been shown to activate their expression, but the mechanism by which these signals are perceived is still unknown. Group I hrp genes in $P$. syringae and Erwinia and Pantoea spp. are regulated by HrpS and the alternative sigma factor HrpL (Frederick et al. 1993; Xiao and Hutcheson 1994; Xiao et al. 1994; Wei and Beer 1995). Expression of $h r p L$ requires the alternate sigma factor $\sigma^{54}$ in addition to the NtrC-like transcriptional activator HrpS (Frederick et al. 1993; Hendrickson et al. 2000a). In P. syringae, HrpR, which is homologous to HrpS, is also required for full activation of the $h r p L$ promoter and may form heteromeric complexes with HrpS (Hutcheson et al. 2001). In Erwinia amylovora, Wei and associates (2000) described a two-component signal transduction system, HrpX/HrpY, which is orthologous to the one described in this work. They proposed that both HrpS and HrpY regulate hrpL and that their effects are addi- 
tive. In contrast, Group II hrp genes in Xanthomonas and Ralstonia spp. are regulated by AraC-like transcriptional activators. In Ralstonia solanacearum, a complex regulatory cascade transduces a signal arising from contact with the plant cell wall and activates hrp gene expression (Aldon et al. 2000; Brito et al. 2002)

In this report, we describe the sequences and function of genes included in Pantoea stewartii hrp complementation groups V through VII, which were previously identified as regulatory loci (Frederick et al. 2001). hrpS (formerly designated wtsA) was characterized by Frederick and associates (1993), and its sequence is analyzed again here in the context of new data. Using mutational and epistasis analysis, we determined the Hrp phenotype of individual regulatory genes and the order of the steps in the regulatory cascade. The results of this study support a model in which phosphorylated HrpY activates $h r p S$ in response to enviromental stimuli. This is different from the pathway reported for Erwinia amylovora but similar to that concurrently discovered in Erwinia herbicola (synon. Pantoea agglomerans) pv. gypsophilae (Nizan-Koren et al. 2002).

\section{RESULTS}

\section{Sequence analysis}

of the hrp regulatory region of Pantoea stewartii.

The hrp regulatory region was identified by transposon mutagenesis and shown to contain three complementation groups (Frederick et al. 2001). The region was subcloned from the cosmid pES1044 into two contiguous plasmids, pRF8 and pRF201SK (Fig. 1). Prior sequencing of pRF8 (Frederick et al. 1993) revealed a single open reading frame (ORF), hrpS, that encodes an NtrC-like enhancer protein homologous to HrpS from $P$. syringae pathovars (Rahme et al. 1991; Xiao et al. 1994), Erwinia amylovora (Wei et al. 2000), and Erwinia herbicola pv. gypsophilae (Mor et al. 2001). The main features of hrpS have been previously described (Frederick et al. 1993). The sequence of the pRF201SK insert revealed three ORFs between $h r p J$ and $h r p S$, which have been designated $h r p L, h r p X$, and $h r p Y$. All of the ORFs in the regulatory region are transcribed from right to left, as shown in Figure 1. Sequence analysis of the region upstream of $h r p L$ revealed a $\sigma^{54}$ consensus box $\left(\right.$ CTGGCA-N ${ }_{6}$-TTGCT; probability score $\left.=0.92\right)$ at $51 \mathrm{bp}$ from the start codon of hrpL. This was preceded by an $\mathrm{A}+\mathrm{T}$-rich region containing putative integration host factor (IHF) binding elements. A single dyad-symmetrical site (TGCAA-N ${ }_{4}$-TTGCA), weakly matching the NtrC-dependent upstream activating site (TGCACC-N 5 -GGTGCA) (Porter et al. 1995), was located at $-163 \mathrm{bp}$. The predicted $21.3-\mathrm{kDa}$ protein encoded by $h r p L$ is homologous to alternate sigma factors of the ECF $\sigma^{70}$ family (Lonetto et al. 1994), including HrpL of Erwinia amylovora (E value $=3 \mathrm{e}-74,75 \%$ identity) (Wei and Beer 1995), Erwinia herbicola pv. gypsophilae $(\mathrm{E}=2 \mathrm{e}-79$, $80 \%$ identity) (Mor et al. 2001), and P. syringae pathovars (E = 6e-30, 47 to $48 \%$ identity) (Rahme et al. 1991; Xiao and Hutcheson 1994).

The $h r p X$ ORF is located 144 bp downstream from the stop codon of $h r p L$. A weak $\sigma^{70}$ promoter consensus sequence (TGTGGA-N ${ }_{17}$-TAACAA, probability score $=0.87$ ) is located at -22 bp. Only $30 \mathrm{bp}$ separates $h r p X$ from the downstream $h r p Y$ gene. The predicted proteins encoded by $h r p X$ (485 aa) and $h r p Y$ (213 aa) have homology to bacterial two-component signal transduction systems, with HrpX similar to "orthodox" sensor kinases and HrpY similar to bacterial response regulators (Hoch and Silhavy 1995). HrpX has two tandem PAS domains (Taylor and Zhulin 1999) in the input region. HrpY belongs to the FixJ class of response regulators with a conserved aspartate (D57), which is the putative site of phosphorylation, as inferred from multiple sequence alignments (not shown). The closest PSI-BLAST matches in the GenBank database for these two genes were the ortholog $\mathrm{HrpX} / \mathrm{HrpY}$ proteins of $\mathrm{Er}$ winia herbicola pv. gypsophilae $(\mathrm{E}=0,79 \%$ identity for HrpX; E = e-103, 88\% identity for HrpY) (Mor et al. 2001) and Erwinia amylovora $(\mathrm{E}=0,79 \%$ identity for $\operatorname{HrpX} ; \mathrm{E}=2 \mathrm{e}-$ 96, 84\% identity for HrpY) (Wei et al. 2000). Interestingly, a putative $\mathrm{HrpX}$ and HrpY orthologous pair $(\mathrm{E}=3 \mathrm{e}-40$ for $\mathrm{HrpX} ; \mathrm{E}=9 \mathrm{e}-39$ for $\mathrm{HrpY}$ ) is also present in $P$. syringae DC3000 (as found on the National Center for Biotechnology Information website).

Our sequence analysis did not reveal any Rho-independent terminators immediately following the end of $h r p Y$, and multiple translational stops are present in the 842-bp hrpY-hrpS intergenic region. BLAST searches of the GenBank database indicated that a 483-bp IS-like element is present at -23 bp from the start of hrpS (Fig. 1). This putative IS element is flanked by two 8-bp direct repeats and contains two 75-bp imperfect inverted repeats. The latter match sequences flanking unidentified prophage genes and integrases present in the chromosomes and virulence plasmids of Salmonella typhimurium and S. typhi (GenBank accession numbers AE006471, AE008744, and AL627268) and also flanking virulence ORFs 2 and 3 in $P$. syringae pv. phaseolicola plasmid pAV511 (accession number AF141883). However, the IS-like element in Pantoea stewartii does not contain an ORF. Several putative $\sigma^{70}$ promoter sequences are present upstream of and inside the IS-like element. Polymerase chain reaction (PCR) analysis of 11 strains from a geographically representative collection revealed that this IS remnant was present in the same physical position in all strains tested (data not shown).

\section{Null mutant phenotypes and epistasis analysis.}

In a previous study, we isolated Tn5 and Tn $3 \mathrm{HoHoI}$ insertion mutations in $h r p L, h r p X, h r p Y$, and $h r p S$ and recombined

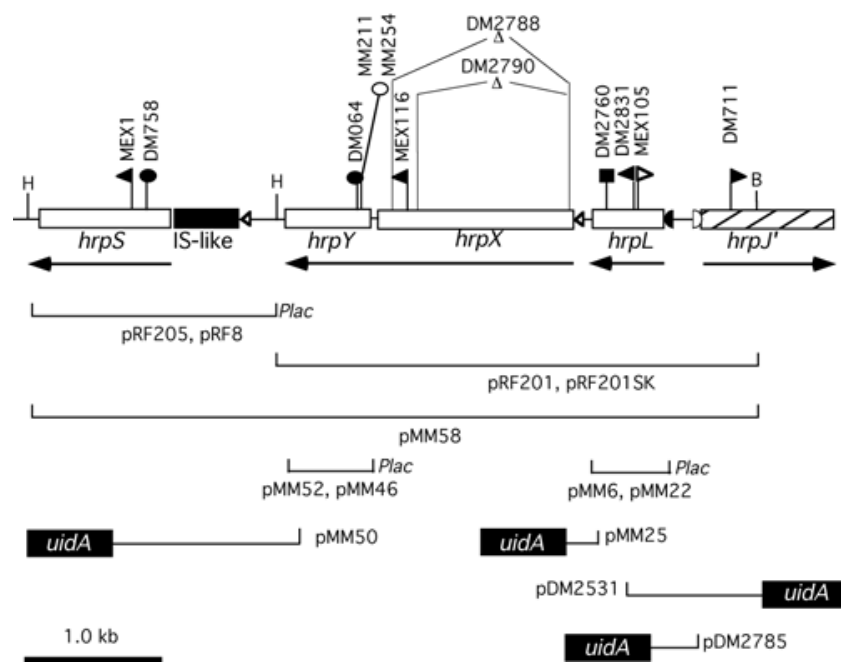

Fig. 1. Physical map of the regulatory region of the Pantoea stewartii DC283 hrp gene cluster showing the $h r p L, h r p X$, $h r p Y$, and $h r p S$ subclones used in this study. Open boxes represent regulatory open reading frames, the cross-hatched box is $h r p J$, a secretion operon, and the solid box represents an IS remnant in the $h r p S 5$ ' regulatory region. The direction of transcription is shown by arrows. Solid circles indicate $\mathrm{Tn} 5$ insertions, the open circles are point mutations, flags indicate $\mathrm{Tn} 3 \mathrm{HoHoI}$ insertions and their orientation, squares denote $a p h A-3$ insertions, and $\Delta$ indicates in-frame deletions. Open triangles in front of genes represent putative $\sigma^{70}$ promoters, the closed semicircle is a $\sigma^{54}$ promoter, and the open semicircle is a $h r p$ box promoter. $\mathrm{P}_{l a c}$ indicates the position of the constitutive lac promoter in the plasmid vector. Solid boxes labeled "uidA" indicate transcriptional fusions to the GUS gene in pL6GUSC. Restriction enzyme abbreviations: H, HindIII, B, BamHI. 
them into the genome of Pantoea stewartii wild-type strain DC283, producing strains hrpL::Tn3HoHoI (MEX105), hrpX::Tn3HoHoI (MEX116), hrpY::Tn5 (DM064), and hrpS::Tn5 (DM758) (Fig. 1) (Frederick et al. 2001). All of these mutants have a $\mathrm{Hrp}^{-}$phenotype, cannot synthesize harpin, and exhibit down-regulation of several cosmid-borne hrp-lacZ fusions in secretion genes. Since transposon mutations in $h r p X$ are polar on $h r p Y$, we constructed two new nonpolar, in-frame, deletion mutants of $h r p X, \quad \Delta h r p X_{(17-414)}$ (DM2790) and $\Delta h r p X_{(17-470)}(\mathrm{DM} 2788)$ (Fig. 1). In tobacco, the newly constructed $\Delta h r p X$ mutants were unable to produce HR symptoms, even when infiltrated at high cell densities $\left(>10^{9}\right.$ $\mathrm{CFU} \mathrm{ml} \mathrm{m}^{-1}$ ). On sweet corn seedlings, mean disease severity ratings at 3 days after inoculation were $2.9 \pm 0.2$ and $1.9 \pm 1.0$ for DC283 and DM2790, respectively. Although these means are not significantly different at $P=0.05$, we observed large variations in both infection rates and symptom severity with the mutant but not with the wild-type strain. In general, the $\Delta h r p X$ mutants were capable of attaining wild-type levels of virulence but with variable response times and incidence. This may mean that the $h r p X$ mutants are much more sensitive to physiological differences between individual seedlings.

Complementation analysis was done to determine the epistatic interactions between different genes and rule out the possibility that some phenotypes were due to second-site mutations. Low copy number plasmids (pRK415 or pLAFR3) carrying $h r p X Y^{+}, h r p Y^{+}, h r p S^{+}$, and $h r p L^{+}$(Fig. 1) were constructed and introduced into different mutants. The ability of these plasmids to restore HR elicitation in tobacco and virulence on sweet corn to the mutants was tested. In all cases where virulence was restored, the complemented mutants were fully virulent (disease severity rating $\geq 2.5$ in at least two experiments), and the bacteria did not need to be preinduced in inducing medium (IM) to cause the HR. The $\mathrm{P}_{l a c}-h r p L$ plasmid pMM6 restored HR elicitation in tobacco and virulence on sweet corn to all the insertion and deletion mutants in the regulatory region. Next, the $\mathrm{P}_{l a c}-h r p S$ plasmid pRF205 was able to restore the $\mathrm{Hrp}^{+}$phenotype to strains with mutations in $h r p X$, hrpY, or both (strains MEX116, DM2788, DM2790, DM064) and hrpS (DM758) and to a double hrpY hrpS mutant (DM733), but not to an $h r p L$ mutant (MEX105). Finally, plasmid pMM52, which contains $\mathrm{P}_{\text {lac }}-h r p Y$, was able to restore HR elicitation and full virulence to $\Delta h r p X$ (DM2788, DM2790) and $h r p Y$ (DM064) mutants, but not to hrpS (DM758) and hrpL (MEX105) mutants. Based on the observations that: i) mutations in $h r p S$ were not suppressed by $h r p Y^{+}$, ii) constitutive expression of $h r p S^{+}$or $h r p L^{+}$restored the $\mathrm{Hrp}^{+}$phenotype to $h r p S$ and $h r p Y$ hrpS mutants, and iii) constitutive expression of $h r p Y^{+}$and $h r p S^{+}$alleles did not overcome the $\mathrm{Hrp}^{-}$phenotype of $h r p L$ mutants, we propose the following basic model for the Hrp regulatory cascade: $h r p Y \rightarrow h r p S \rightarrow h r p L \rightarrow h r p$ box promoters.

\section{Expression of $h r p$ regulatory genes in different genetic backgrounds.}

To confirm the order of the regulatory cascade, $h r p Y:: \operatorname{Tn} 5$, hrpS::Tn5, and hrpL::aphA3 insertions were introduced into the chromosome of selected hrp-lacZ or hrp-uidA strains to create double regulatory mutants. In addition, we tested the effects of constitutively expressing various plasmid-borne regulatory genes on chromosomally located lacZ and uidA transcriptional fusions to $h r p X, h r p S$, $h r p L$, and $h r p J$ promoters. Low copy number plasmids carrying $\mathrm{P}_{l a c}-h r p Y, \mathrm{P}_{l a c}-h r p S$, and $\mathrm{P}_{l a c}-h r p L$ were used to overexpress these genes, and $\beta$ galactosidase or $\beta$-glucuronidase (GUS) activity of the reporter fusions was measured, following induction in IM liquid medium. Results from these experiments are summarized in Figure 2.
A second-site mutation in $h r p Y$ abolished expression of hrpS-lacZ and hrpL-uidA (Fig. 2C), and a mutation in hrpS decreased expression of $h r p L-u i d A$ (Fig. 2B), as expected from the epistatic analysis. Overexpressing $h r p Y$ turned up the $h r p X$ lac $Z$ fusion approximately twofold (Fig. 2A), showing that $h r p X Y$ is a potentially autoregulated operon. $\mathrm{P}_{l a c}-h r p Y$ stimulated the $h r p S$-lacZ fusion approximately eightfold in a $h r p Y^{+}$ background and approximately 20-fold in a $h r p Y h r p S$-lacZ double mutant (Fig. 2B). $\mathrm{P}_{l a c}-h r p Y$ also up-regulated $h r p L$ approximately sevenfold in the $h r p Y^{+}$chromosomal background and approximately fivefold in the $h r p Y$ hrpL-uidA double mutant, but it repressed $h r p L$ expression in the $h r p S$ hrpL-uidA double mutant (Fig. 2C). The inability of HrpY to increase hrpJ expression in strains containing a second-site hrpS or hrpL mutation (strains DM701 and DM786) further indicates that it does not directly activate $h r p L p$ or $h r p$-box promoters, respectively (Fig. 2D). In a $h r p S^{+} h r p X Y^{+}$background, the $\mathrm{P}_{l a c}{ }^{-}$ $h r p S$ plasmid up-regulated both $h r p L$-uidA and hrpJ-lacZ fusions twelve- and threefold, respectively (Figs. 2C and D). This effect was even more apparent in the hrpS hrpJ-lacZ and $h r p Y$ hrpJ-lacZ double mutants, in which expression increased 44- and 82-fold, respectively (Fig. 2D). However, $\mathrm{P}_{\text {lac }}$-hrpS did not affect $h r p J$ expression in a $h r p L$ hrpJ-lacZ double mutant (Fig. 2D), demonstrating that it does not directly affect genes with $h r p$ box promoters. Finally, the $\mathrm{P}_{l a c}-h r p L$ plasmid up-regulated hrpJ-lacZ fusions in all genetic backgrounds ( $h r p X Y$, $h r p Y, h r p S$, and $h r p L$; Fig. 2D), thereby confirming that $h r p L$ is the last gene in the hrp regulatory cascade. Significantly, the expression of the hrpJ-lac fusions in this experiment mirrored the virulence of the same strains in the above mutational and epistasis analysis.

Since the lack of apparent terminators following the $h r p L$ and $h r p X Y$ operons means that transposon-induced mutations could have partial polar effects on the level of expression of downstream genes, we repeated the above experiments with plasmidborne, reporter gene fusions in trans to the tested regulatory mutations. Therefore, we constructed a series of reporter fusions in pPL6GUS. These plasmids contained the regulatory regions upstream of the $h r p X, h r p S$, and $h r p L$ ORFs fused to a uidA reporter gene with its own ribosomal binding site (Fig. 1). Following induction in IM liquid medium, expression of each promoter was assayed in wild-type strain DC283 and in mutants lacking a $h r p$ regulatory gene (Table 1 ). Transcription from the $h r p X p$ region, between -198 and +46 bp from the $h r p X$ start, was high and constitutive in DC283. Expression of the hrpS-uidA fusion, containing the region between -928 and $+384 \mathrm{bp}$, was reduced up to tenfold in $h r p Y$ and $\Delta h r p X$ mutants, as compared with DC283. The hrpL-uidA fusion was reduced approximately 250fold in $h r p S, \Delta h r p X$, and $h r p Y$ mutants.

Since Wei and associates (2000) proposed that HrpS and HrpY both directly activate hrpL in Erwinia amylovora, we recreated each step of the Pantoea stewartii regulatory cascade in Escherichia coli SФ200, a genetic background that would lack other known hrp-specific regulatory molecules. We constructed $E$. coli strains that harbored one of the above low copy hrp-uidA reporter plasmids along with a high copy number plasmid that overexpressed a regulatory gene (plasmids pMM46, pRF8, pMM22 carrying hrpY, hrpS, and hrpL, respectively). These strains were grown in LB broth, the regulatory gene was induced with IPTG, and the cells were assayed for GUS activity. (The following data are expressed as means \pm standard deviation. They are from representative experiments with at least three replicates each, and statistical significance $P$ was analyzed by ANOVA). The hrpXp-uidA fusion in pMM25 was constitutively expressed in $E$. coli but was further stimulated as much as sixfold by overexpression of $h r p Y$ (from $26 \pm$ 6 to $127 \pm 10$ units; $P<0.05$ ). The $h r p S$-uidA fusion carried by 
pMM50 was up-regulated eightfold by HrpY (from $5 \pm 2$ to 42 \pm 5 units; $P<0.05$ ), and the hrpL-uidA fusion in pDM2785 was activated by HrpS (30-fold from $79 \pm 20$ to $2,370 \pm 817$ units; $P<0.001$ ). In contrast, overexpression of $h r p Y$ did not enhance $h r p L p$ expression, but instead, it consistently repressed its basal level by approximately sixfold (from $79 \pm 20$ to $12 \pm 3$ units; $P<0.001)$. Finally, the hrpJp-uidA fusion, which contains a promoter with an $h r p$-box, was strongly activated by $h r p L$ expressed from plasmid pMM22 (2,000-fold induction from 2 to 3,970 units; $P<0.001$ ).

Overall, our data support a model in which HrpY autoregulates $h r p X Y$ expression, stimulates $h r p S$ transcription, and represses $h r p L$. These results further confirm that HrpS activates $h r p L$ and then HrpL alone controls expression of hrp box promoters.

\section{Role of the conserved aspartate in HrpY.}

Based on sequence homology and protein modeling (analysis not shown), the conserved aspartate residue at position 57 is the most likely phosphorylation site in HrpY. To test if D57 is required for activation of $\mathrm{HrpY}$, we mutated this codon to alanine and asparagine. Both substitutions were expected to prevent phosphorylation while minimizing structural effects on the protein, as shown for similar response regulators (Hoch and Silhavy 1995; Jin et al. 1990; Moore et al. 1993). The missense mutant alleles were constructed in vitro by spliced overlap extension PCR and exchanged for the wild-type locus in the chromosome of DC283, using the positive selection, suicide vector pLD55. Both the $h r p Y(\mathrm{D} 57 \mathrm{~N})$ and the $h r p Y$ (D57A) chromosomal mutants were completely unable to infect corn whorls or to elicit the HR when infiltrated into tobacco leaves: they were complemented for both phenotypes by the $\mathrm{P}_{l a c}-h r p Y$ plasmid, pMM52. Unexpectedly, low copy number plasmids carrying the same mutant alleles, pMM74 $\mathrm{P}_{l a c}-h r p Y(\mathrm{D} 57 \mathrm{~A})$ and pMM118 $\mathrm{P}_{\text {lac }}-h r p Y(\mathrm{D} 57 \mathrm{~N})$, were also able to complement the null phenotype of the D57A, D57N, and Tn5 hrpY chromosomal mutants. As discussed below, this type of overexpression artifact is common with two-component regulators and necessitates the use of single copy mutant alleles for assessing phenotypes.

\section{Effects of environmental conditions on the expression of hrp genes in vitro.}

The regulatory effects of $\mathrm{pH}$, phosphate, ammonia, and sodium chloride were tested in vitro using chromosomal hrpXlacZ, hrpS-lacZ, and hrpJ-lacZ fusions (Fig. 3). IM was used as a basal medium to test each variable. Expression of $h r p S$ lac $Z$ and $h r p J-l a c Z$ was decreased by neutral to basic $\mathrm{pH}$ values (with maximal expression at $\mathrm{pH}$ 5.5) and by high potassium phosphate, ammonium chloride, and sodium chloride levels. When we plotted the dose-response curves for each salt expressed as its osmotic pressure (calculated by approximating activities to concentration values), the curves overlapped (data not shown), implying that part of the ability of IM to induce hrp genes could be due to its low osmolarity per se rather than to nitrogen or phosphate starvation. In contrast, expression of hrpX-lacZ was not affected by $\mathrm{pH}$ and was only slightly reduced by addition of the three salts (Fig. 3). In rich culture media, plasmid pRF205 $\mathrm{P}_{l a c}-h r p S$ relieved repression of promoters downstream of hrpS in the cascade (data not shown). This was consistent with the ability of pRF205 to enable Pantoea stewartii to elicit a HR in tobacco, irrespective of the media used to grow the inoculum. We also tested the effect of $2 \mathrm{mM}$ nicotinic acid on wild-type DC283 cells carrying pDM2531 hrpJ-uidA during growth in IM, pH 5.5. Expression of this fusion in IM was reduced fivefold by nicotinic acid (from 7,357 \pm 138 to $1,439 \pm 60$ units \pm standard error in two experiments).
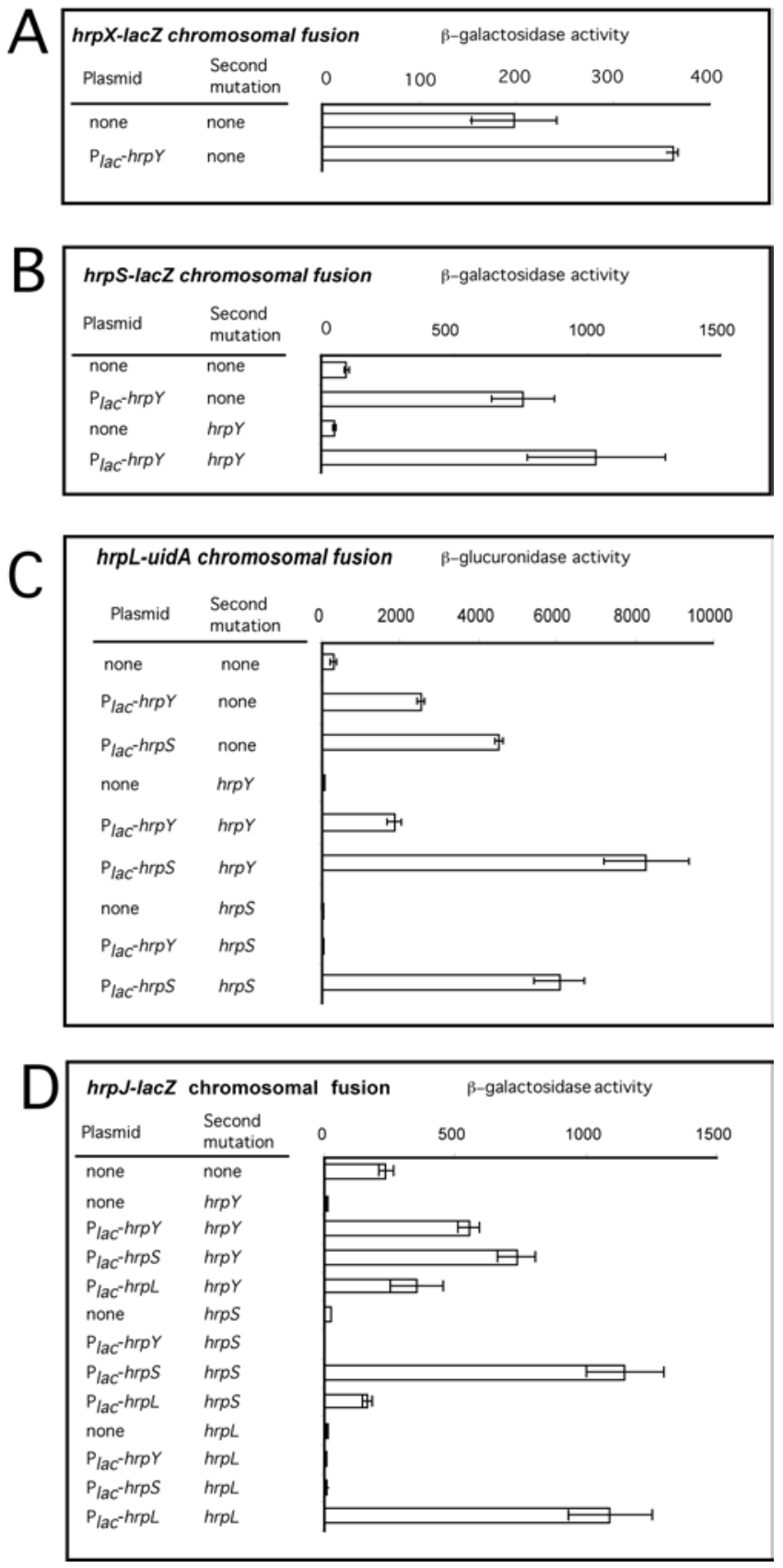

Fig. 2. $\beta$-galactosidase ( $\beta$-Gal) and $\beta$-glucuronidase (GUS) activity of chromosomal hrp-lacZ or hrpL-uidA fusions in different Pantoea stewartii genetic backgrounds, with and without various plasmid-borne $\mathrm{P}_{l a c}-h r p$ regulatory genes. A, $\beta$-Gal activity in hrpX-lacZ strain MEX116. B, $\beta$ Gal activity in the hrpS-lacZ strain MEX1 and hrpY hrpS-lacZ strain DM733. C, GUS activity in hrpL-uidA strain DM2831, hrpY hrpL-uidA strain DM2837 and hrpS hrpL-uidA strain DM2844. D, $\beta$-Gal activity in the hrpJ-lacZ strain DM711, hrpY hrpJ-lacZ strain DM729, hrpL hrpJlacZ strain DM786, and $\Delta h r p S$ hrpJ-lacZ strain DM701.Cells were grown in inducing medium, $\mathrm{pH} 5.5$, broth to late log phase, and $\beta$-Gal-

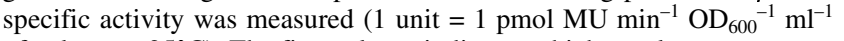
of culture at $25^{\circ} \mathrm{C}$ ). The first column indicates which regulatory gene was constitutively expressed in trans (if any); the second column indicates the second hrp mutation (if any) in the strain. Regulatory gene clones: pMM52 $\mathrm{P}_{l a c}-h r p Y$ and pMM46 $\mathrm{P}_{l a c}-h r p Y$ (C) (low copy pMM330 was used as well, with similar results); pRF205 $\mathrm{P}_{l a c}-h r p S$ (D) and pRF8 $\mathrm{P}_{l a c}{ }^{-}$ $h r p S$ (C); and pMM6 $\mathrm{P}_{l a c}-h r p L$ (D). Controls consisting of the vector plasmids without inserts had no effect on expression of any of the gene fusions. 


\section{DISCUSSION}

Bacterial virulence factors are usually tightly regulated and controlled by environmental stimuli (Finlay and Falkow 1997). Mediating these signals are complex, often hierarchical, regulatory cascades that integrate multiple inputs and finely tune the infection process. The cascades controlling type III and type IV secretion systems in several mammalian and plant pathogens have been shown to include complete or partial twocomponent signal transduction pairs. These constitute a common strategy for linking the expression of energy-consuming secretion apparatuses to signals indicating the presence of a host. In this study, we present evidence for a regulatory cascade that activates $h r p / h r c$ type III secretion/effector genes in Pantoea stewartii in response to in vitro stimuli that mimic the host environment. The cascade involves, from the top down (Fig. 4), a two-component signal transduction pair (HrpX and HrpY), a transcriptional activator (HrpS), and finally an alternative sigma factor (HrpL). In this study, we first confirmed that HrpS and HrpL serve the same functions in Pantoea stewartii as they do in Erwinia amylovora and $P$. syringae (Hendrickson et al. 2000a, 2000b; Hutcheson et al. 2001; Rahme et al. 1991; Wei and Beer 1995, Wei et al. 2000; Xiao et al. 1992), and then we focused on the role of the HrpX/Y two-component system.

The occurrence of orthologs of HrpX/HrpY in Erwinia amylovora (Wei et al. 2000), Erwinia herbicola pv. gypsophilae (Mor et al. 2001), Erwinia chrysanthemi (J. H. Ham, C. M. Rojas, A. Collmer, unpublished data; GenBank accession no. AF448202) and possibly in P. syringae pv. tomato DC3000 suggests that this two-component system may represent a common mechanism for the environmental regulation of group I hrp genes. However, only the functional and genetic analysis of Erwinia amylovora hrpXY has been published (Wei et al. 2000) to date. The role proposed by Wei and associates (2000) for Erwinia amylovora HrpY is different from the one we present here for Pantoea stewartii in that HrpY appears to serve as a modulator of HrpS activation of $h r p L$ instead of activating $h r p S$. This conclusion was based on their finding that a nonpolar $h r p Y::$ TnphoA mutation did not affect a chromosomal hrpS::Tn5-gusAl reporter and on an earlier observation (Wei and Beer 1995) that a hrpS mutation only partially regulates hrpL. A similar, independent study on hrp gene regulation in Erwinia herbicola pv. gypsophilae has been published concurrently with ours (Nizan-Koren et. al. 2002). Their results with HrpY are in complete agreement with our findings for Pantoea stewartii. Other key data in Wei and associates (2000), such as the inability of $h r p Y$ to complement a $h r p S$ mutation, the downregulation of $h r p L$ in a $h r p Y$ background, and the autoregulation of the $h r p X Y$ operon by HrpY, are consistent with both our results and those in Erwinia herbicola pv. gypsophilae. This suggests that common regulatory elements may interact differently in the pantoeas and some other erwinias than they do in Erwinia amylovora. An extreme example of this is found in Erwinia carotovora, which has both $h r p S$ and $h r p L$. However, $h r p L$ expression in this species is constitutive, and the hrp genes are posttranscriptionally regulated by $\mathrm{RsmA}$, which affects the stability of hrpL mRNA (Chatterjee et al. 2002).

In view of the apparent differences in the role of HrpY between Pantoea stewartii and Erwinia amylovora, we verified our hypothetical model, using multiple approaches. In particular, the regulatory effect of HrpY on hrpS transcription was demonstrated repeatedly by measuring plasmid-borne reporter gene fusions in $h r p$ regulatory mutants (Table 1), by using complementation tests with plasmid-borne $h r p Y^{+}$in $h r p S-l a c Z$ or hrpY::Tn5 hrpS-lacZ strains (Fig. 2B), and by reconstructing individual steps of the cascade in E. coli. Moreover, overexpression of $h r p Y^{+}$repressed the $h r p L$-uidA reporter in both a hrpS background (Fig. 2C) and in E. coli genetic reconstruction experiments, further indicating that HrpY cannot activate $h r p L$. It is possible that repression of $h r p L p$ by unphosphorylated HrpY could provide a way of keeping the basal level of hrp gene expression low under noninducing conditions or provide a mechanism to turn it back down late in infection, or both. We are in the process of obtaining biochemical evidence for the function of HrpY; preliminary experiments indicate that $h r p S p$ is located between the IS-like element and the end of $h r p Y$ and that purified HrpY protein can, indeed, retard a hrpS promoter fragment in gel-shift experiments and also weakly binds to a $h r p L$ promoter fragment (M. Merighi and D. Coplin, unpublished data).

In the course of our complementation experiments, we found that a $\mathrm{P}_{l a c}-h r p Y$ plasmid activated $h r p S p$ in the absence of $h r p X$ and complemented polar $h r p X Y$ mutants. These observations raised the question as to whether or not HrpY always needs to be phosphorylated in order to activate hrp genes. To address this question, we carried out site-directed mutagenesis of the conserved aspartate (D57) in HrpY, which is the putative phosphorylation site, and found that Pantoea stewartii mutants carrying either $\operatorname{hrp} Y(\mathrm{D} 57 \mathrm{~N})$ or $\operatorname{hrp} Y(\mathrm{D} 57 \mathrm{~A})$ chromosomal alleles in single copy were completely $\mathrm{Hrp}^{-}$. This result indicated that D57 is required for HrpY to function as a positive regulator and is genetic evidence that phosphorylation is required for HrpY activation. We believe that the avirulence of these mutants reflects the role of D57 in phosphorylation rather than any nonspecific structural changes brought about by the amino acid substitutions. This role is supported by the solvent-exposed position of this residue (based on 3D protein modeling; data not shown), its conserved position, and the type of substitutions performed, as shown for other well studied receiver domains (Jin et al. 1990; Moore et al. 1993). Consequently, we attribute our finding that plasmid-borne wild-type HrpY and D57 mutant alleles were active in the absence of $h r p X$ to an

Table 1. Effects of hrp regulatory genes on plasmid-borne hrp::uidA transcriptional fusions expressed in different genetic backgrounds ${ }^{\mathrm{a}}$

\begin{tabular}{|c|c|c|c|c|c|c|}
\hline \multirow[b]{2}{*}{ Plasmid } & \multirow[b]{2}{*}{ Promoter fusion ${ }^{b}$} & \multicolumn{5}{|c|}{ GUS activity (Units \pm S. E.) ${ }^{c}$ in different genetic backgrounds ${ }^{d}$} \\
\hline & & Wild type & $\Delta h r p X$ & hrpY & hrpS & hrpL \\
\hline pMM25 & $-198 /+46$ hrpXp & $307 \pm 53$ & $370 \pm 104$ & $206 \pm 2$ & ND & ND \\
\hline pMM50 & $-928 /+384$ hrpSp & $135 \pm 9$ & $20 \pm 9$ & $21 \pm 4$ & $119 \pm 12$ & ND \\
\hline pDM2785 & $-207 /+182$ hrpLp & $6053 \pm 959$ & $164 \pm 5$ & $67 \pm 12$ & $36 \pm 1$ & ND \\
\hline pDM2531 & $-516 /+425$ hrpJp & $4851 \pm 704$ & $94 \pm 13$ & $17 \pm 5$ & $3 \pm 1$ & $0 \pm 0$ \\
\hline pDM2791 & $-914 /+22 w t s E p$ & $399 \pm 125$ & $7 \pm 5$ & $1 \pm 1$ & $0 \pm 0$ & $4 \pm 2$ \\
\hline
\end{tabular}

${ }^{a}$ Strains were grown in inducing medium broth, $\mathrm{pH}$ 5.5, to late exponential-early stationary phase and were assayed for GUS activity fluorometrically, using 4methyl-umbelliferyl- $\beta$-D-glucuronide as described by Jefferson (1987), but the assays were scaled down to fit microtiter plates and were analyzed using a Victor 1420-2 multilabel reader.

b Transcriptional fusion names are preceded by the promoter fragment coordinates in bp ( +1 is first base of ORF).

${ }^{c}$ One unit $=1 \mathrm{pmol} \mathrm{MU} \mathrm{min}{ }^{-1} \mathrm{OD}_{600}{ }^{-1} \mathrm{ml}^{-1}$ of culture at $37^{\circ} \mathrm{C}$. S. E. = standard error of two to six independent experiments, each with at least two replicates.

${ }^{\mathrm{d}}$ Strains: wild type $=\mathrm{DC} 283 ; \Delta h r p X=\mathrm{DM} 2790$ (mutant DM2788 gave similar results); $h r p Y=\mathrm{DM} 064 ; h r p S=\mathrm{DM} 758$ or MEX1; $h r p L=\mathrm{MEX} 105$. 
overexpression artifact that is commonly encountered in genetic studies of two-component systems (Hoch and Silhavy 1995). For example, in E. coli, overexpression of UhpA (a related FixJ-class response regulator) activated its target promoter $u h p T p$. This overexpression effect was observed with both wild-type UhpA and a D54A mutant protein (ShattuckEidens and Kadner 1983; Kadner 1995). Two common explanations for this phenomenon are cross-talk with paralog kinases and the ability of the unphosphorylated response regulator to bind promoters at abnormally high concentrations (Hoch and Silhavy 1995).

In general, hrp genes are induced in minimal media that mimic conditions found in planta (Lindgren 1997), but these can vary considerably between species. For example, hrp genes in Erwinia amylovora are stimulated by low $\mathrm{pH}$ and repressed by glucose, ammonium salts, asparagine, histidine, and nicotinic acid, but are unaffected by osmolarity (Wei et al. 1992). P. syringae hrp genes are likewise induced at low $\mathrm{pH}$ in minimal media, but they are nonspecifically repressed by high salt concentrations (Rahme et al. 1992). The results of our study showed that expression of many hrp genes in Pantoea stewartii was similarly regulated by $\mathrm{pH}$ and nitrogen sources but, in contrast to Erwinia amylovora, they were also affected by salt concentration (Fig. 4). hrpS-lacZ and hrpJ-lacZ chromosomal fusions were inhibited at neutral to basic $\mathrm{pH}$ and at high concentrations of potassium phosphate, sodium chloride, and ammonium sulfate. In a previous study, we found that nitrates are also strongly repressing but casamino acids increase expression rather than repress it (Coplin et al. 1992).

For our studies on the role of the two-component system in sensing environmental signals, we constructed two Pantoea stewartii mutants with different in-frame deletions within the kinase domain of HrpX. In these strains, the expression of $h r p S$, $h r p L$, and $h r p J$ was greatly reduced (to levels comparable to a null hrpY mutant) when assayed in IM (Table 1), and the $\Delta h r p X$ mutants could not cause a HR on tobacco, which in Pantoea stewartii requires preinduction in IM. This is the first clear indication in any system that $\operatorname{HrpX}$ is needed to sense the chemical and physiological signals provided in vitro by an apoplast-mimicking, Hrp-inducing medium. The $h r p X Y$ operon itself maintained a high basal level of expression in both rich media (data not shown) and in IM medium at neutral $\mathrm{pH}$ with added salts (Fig. 3), whereas the hrpS promoter was repressed under these conditions. Thus, $h r p S$ appears to be the first gene in the regulatory cascade that is under strong environmental control, and its transcriptional regulation by phosphorylated HrpY and global regulators (M. Merighi and D. Coplin, unpublished data) may therefore be the key point in the cascade in which environmental signals are integrated.

The exact nature of the signals detected by HrpX is currently under investigation in our laboratory. At this point, however, the sequence analysis of $\mathrm{HrpX}$ offers a possible explanation as to how the hrp regulon is able to respond to such a wide range of environmental conditions. The absence of transmembrane regions indicates that $\mathrm{HrpX}$ is probably a cytoplasmic protein and the presence of duplicated PAS domains in the N-terminal portion suggests that its signal may be internal. PAS domains are versatile cytosolic protein modules involved in monitoring light, redox potential, oxygen, small ligands, and the energy level inside cells (Stephenson and Hoch 2001; Taylor and Zhulin 1999). Cluster analysis of a diverse set of PAS domains from prokaryotic sensor proteins revealed that the PAS domains of HrpX are most closely related to those of Azotobacter vinelandii NifL (data not shown), which is a flavoprotein with FAD as its prosthetic group (Taylor and Zhulin 1999). Therefore, by analogy to NifL, HrpX might sense redox potentials and energy changes within the cell. This hypothesis would explain how the Hrp regulon is able to respond to most of the conditions known to induce hrp genes, i.e., acidity, phosphate, and nitrogen starvation, all of which could affect cellular redox potentials.

The importance of HrpX during infection appears similar in Pantoea and Erwinia species in that it is not absolutely required for virulence. In Erwinia amylovora, a nonpolar hrpX::TnphoA mutant was greatly reduced in virulence, response time, and growth in planta, and the expression of hrpL was reduced fivefold in IM (Wei et al. 2000). In contrast, a nonpolar hrpX::mini-Tn10-Km mutant of Erwinia herbicola pv. gypsophilae remained fully virulent and did not show any decrease in downstream hrp gene expression in planta, but the effect of this mutation was not determined in an inducing medium (Nizan-Koren et al. 2002). Since the basis for the nonpolarity of TnphoA and mini-Tn 10 transposons in Erwinia spp. is not understood, it is possible that $h r p Y$ was not expressed at normal levels in these experiments. The two Pantoea stewartii $\Delta h r p X$ mutants used in this study were only slightly reduced in virulence, infectivity, and response time, but they exhibited much greater variability in symptom severity and incidence on corn seedlings. This suggests that the ability of the pathogen to sense the nutritional status of its host is very important to insure consistent infection. On the other hand, given that $\Delta h r p X$ mutants still retained significant virulence on sweet corn while nonphosphorylatable mutants of HrpY were totally nonpathogenic, we hypothesize that there is an alternative HrpX-independent pathway leading to HrpY activation in planta. This could reflect either the increased accumulation of small phosphodonor molecules (McCleary et al. 1993) under starvation conditions or the action of an alternative bacterial kinase specifically activated in corn (but not in tobacco or IM). It will be interesting to learn if this alternate phosphorylation pathway responds to host cell contact or to specific plant inducer molecules.

\section{MATERIALS AND METHODS}

Bacterial strains, plasmids, media, and growth conditions.

E. coli and Pantoea stewartii strains and plasmids used in this study are listed in Table 2. Luria-Bertani (LB) broth and agar (Ausubel et al. 1987) were used for strain maintenance and for growth of Pantoea stewartii under Hrp-repressing con-

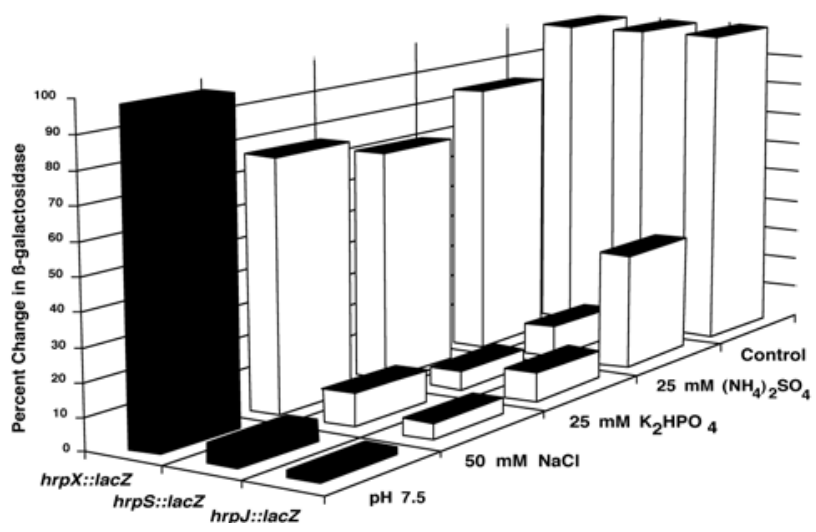

Fig. 3. Effect of environmental conditions on the expression of various hrp-lacZ fusions. The effects of neutral $\mathrm{pH}, 50 \mathrm{mM}$ sodium chloride, 25 $\mathrm{mM}$ ammonium sulfate, and $25 \mathrm{mM}$ potassium phosphate are shown as a percentage of the activity in standard inducing medium (IM), pH 5.5, liquid medium (control). Cells were grown in modified IM, with one component changed, as indicated in the Z-axis of the graph, for $16 \mathrm{~h}$, and $\beta$ Gal activity was measured. hrpX-lacZ = strain MEX116, hrpS-lacZ = strain MEX1, and hrpJ-lacZ = DM711. 
ditions. Fusaric acid-containing tetracycline-sensitive selection medium was prepared as described (Metcalf et al. 1996). To induce hrp genes in Pantoea stewartii strains, overnight LB broth cultures were washed twice in IM (Frederick et al. 2001), were inoculated into $2 \mathrm{ml}$ of the same medium at an optical density at $600 \mathrm{~nm}\left(\mathrm{OD}_{600 \mathrm{~nm}}\right)$ equal to 0.05 , were grown for 12 to $16 \mathrm{~h}$, and were adjusted to a final $\mathrm{OD}_{600 \mathrm{~nm}}$ of approximately 0.5. In the $\mathrm{pH}$ experiment, HEPES and Tris- $\mathrm{HCl}$ buffers were used for the neutral and basic $\mathrm{pH}$ ranges, respectively, in place of MES. Liquid cultures were grown in flasks or tubes shaken at $200 \mathrm{rpm}$ at $37^{\circ} \mathrm{C}$ for E. coli or $29^{\circ} \mathrm{C}$ for Pantoea stewartii. When appropriate, antibiotics were supplied at the following concentrations: ampicillin, $200 \mu \mathrm{g} \mathrm{ml}^{-1}$; kanamycin, $50 \mu \mathrm{g} \mathrm{ml}^{-1}$; and tetracycline, $20 \mu \mathrm{g} \mathrm{ml} \mathrm{g}^{-1}$ (or $15 \mu \mathrm{g} \mathrm{ml} \mathrm{m}^{-1}$ for selection of single copy $\operatorname{Tet}^{\mathrm{r}}$ cointegrates).

\section{HR and pathogenicity tests.}

To test for HR elicitation on tobacco (Nicotiana tabacum L. cv. "White Burley") plants, Pantoea stewartii strains were grown overnight in IM liquid medium, were washed, and were resuspended in water at $\mathrm{OD}_{600 \mathrm{~nm}}=0.52$ (approximately $1 \times 10^{9}$ $\mathrm{CFU} \mathrm{ml} \mathrm{m}^{-1}$ ). Cells were infiltrated into tobacco leaves using four replicates per strain as previously described (Frederick et al. 2001), and necrosis was rated 24 to $48 \mathrm{~h}$ after infiltration. Pathogenicity tests were performed by inoculating the whorls of five-day-old sweet corn seedlings (Zea mays var. saccharata cv. "Seneca Horizon") as previously described (Coplin et al. 1986). The plants were held in growth chambers at $29^{\circ} \mathrm{C}(16 \mathrm{~h}$ photoperiod, 15,000 lux, 99\% relative humidity). After three days, disease severity was rated using a 0 to 3 scale $(0=$ no symptoms, 1 = scattered small lesions, 2 = numerous lesions, and 3 = extensive lesions that remained water-soaked with ooze forming on leaf surfaces).

\section{General recombinant DNA,} genetic, and bioinfomatic techniques.

DNA isolation, agarose gel electrophoresis, restriction enzyme digestion, and ligation were done following standard procedures (Ausubel et al. 1987). PCRs used either native Taq (for colony PCR screens and construct mapping) or cloned Pfu (for molecular cloning) DNA polymerases (Invitrogen, Carlsbad, CA, U.S.A and Clontech, Palo Alto, CA, U.S.A., respectively)

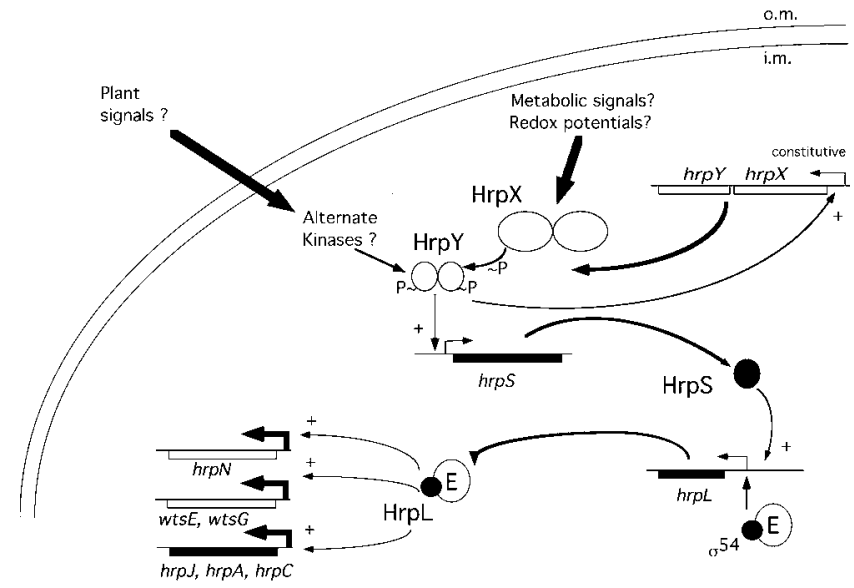

Fig. 4. Working model for the hrp regulatory cascade in Pantoea stewartii. The HrpX sensor perceives undefined metabolic and stress signals and activates HrpY via phosphorylation (indicated by $\sim \mathrm{P}$ ). A parallel phosphorylation mechanism may also activate HrpY in planta. HrpY then activates hrpS and its own operon; HrpS and $\sigma^{54}$ activate $h r p L$; and finally, HrpL enables RNA polymerase core enzyme (E) to activate promoters containing hrp boxes (e.g., the harpin, wts, and hrp secretion genes). and standard amplification protocols (Ausubel et al. 1987). For colony PCR, we used cells lysed in $50 \mathrm{mM} \mathrm{NaOH}$ for $10 \mathrm{~min}$ at $100^{\circ} \mathrm{C}$ as templates. For pBluescript and pRK415 vectors, the reactions were performed using one primer anchored on either the lacI vector gene (primer LACF) or the $\alpha$ lacZ gene fragment (primer LACR) and a second primer conveniently located in the recombinant insert (Table 3). Standard deprotected oligonucleotide primers were ordered from IDT-DNA (Coralville, IA, U.S.A.). Probes for Southern blot hybridizations were labeled with 11-Dig-dUTP, and colorimetric immunodetection was done as recommended by the manufacturer (Roche Biochemicals, Indianapolis, IN, U.S.A.). Plasmids were introduced into E. coli and Pantoea stewartii strains by electroporation, chemical transformation (Inoue et al. 1990), or mobilized by triparental mating using pRK2013::Tn7 as a helper plasmid (Ditta et al. 1980).

DNA sequencing was performed using cycle sequencing with fluorescent dye terminator chemistry and the ABI 3700 capillary electrophoresis sequencer (PE-Applied Biosystems, Wellesley, MA, U.S.A.) at The Ohio State University PlantMicrobe Genomic Facility. Database analyses of predicted proteins were performed using BLAST/PSI-BLAST (Altschul et al. 1997), whereas conserved domain analysis used the CD search service (ver. 1.54) (Marchler-Bauer et al. 2002), both available through the National Center for Biotechnology Information. Statistical significance of the matches are reported as E values. Promoter searches were performed using a neural network prediction algorithm (Reese et al. 1996; available on the Berkely Drosophila Genome Project website) and the IHF/Sigma54 promoter-finder program (Goodrich et al. 1990).

\section{Construction}

of $\mathbf{P}_{l a c}$-hrpY, $\mathbf{P}_{l a c}-h r p S$, and $\mathbf{P}_{l a c}-h r p L$ plasmids.

For complementation and overexpression experiments, the $h r p X, h r p Y$, and $h r p L$ ORFs, including their ribosomal binding sites, were amplified by PCR and were cloned into high and low copy number cloning vectors, such that they were expressed from $\mathrm{P}_{\text {lac }}$ (Fig. 1). E. coli $\mathrm{DH} 10 \mathrm{~B}$ was used as a cloning host. In all cases, cosmid pES1044 or plasmid pMM58 were used as templates for the amplification reactions. PCR products were gel-purified, were digested with appropriate restriction enzymes, and then, were ligated into pBluescript $\mathrm{KS}(+)$ or pBluescript $\mathrm{SK}(+)$ (Stratagene, La Jolla, CA, U.S.A.). Clones containing recombinant plasmids were screened by colony PCR, using the LacF primer and the reverse primer used for the PCR cloning. Individual genes were subsequently subcloned into the low copy mobilizable vector pRK415 (Keen et al. 1988) such that they were transcribed from $\mathrm{P}_{l a c}$. Vectors and recombinant plasmids are listed in Table 2 and primers in Table 3.

$h r p Y$ was amplified using primers YFH and YRH. The 675-bp amplicon was cloned into pBluescript $\mathrm{KS}(+)$ to produce pMM46 and then subcloned into pRK415 to produce pMM52. hrpL, without its $\sigma^{54}$-dependent promoter, was amplified using primers LFB and LRE. The 613-bp PCR fragment was cloned into pBluescript $\mathrm{SK}(+)$ to produce pMM22 and then was subcloned into pRK415 to produce pMM6. The construction of $\mathrm{P}_{\text {lac }}-h r p S$ expression plasmids pRF205 (low copy) and pRF8 (high copy) and the $h r p X Y$ plasmid pRF201 was previously described (Frederick et al. 1993). Plasmid pMM58, containing the entire regulatory region, was constructed by ligating the 1.7-kb HindIII insert of pRF8 into pRF201SK digested with HindIII.

\section{Construction}

of chromosomal Pantoea stewartii hrp insertion mutants.

Construction of Tn5 and Tn $3 \mathrm{HoHoI}$ mutants with insertions in $h r p X, h r p Y, h r p S$, and $h r p L$ has been previously described (Frederick et al. 2001). Double mutants containing selected 
Table 2. Bacterial strains and plasmids.

\begin{tabular}{|c|c|c|}
\hline Strain or plasmid & Relevant phenotypes and genotypes & Source or reference \\
\hline \multicolumn{3}{|l|}{ Escherichia coli } \\
\hline BW20339 & 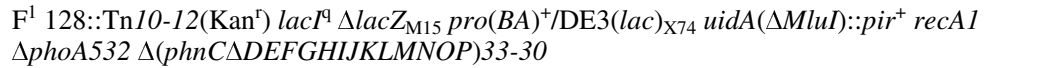 & Metcalf et al. 1996 \\
\hline DH10B & $\begin{array}{l}\mathrm{F}^{-} \text {mcrA } \Delta(\text { mrr-hsdRMS-mcrBC) } \phi 80 \mathrm{~d} \text { lacZAM15 } \triangle l a c X 74 \text { endA1 recAl deoR } \\
\Delta(\text { ara,leu }) 7697 \text { araD139 galU galK nupG rpsL } \lambda^{-}\end{array}$ & Gibco BRL \\
\hline HB101 & $\mathrm{F}^{-}$thi-1 hsd20 $\left(\mathrm{(}_{\mathrm{B}}^{-} \mathrm{m}^{-}{ }_{\mathrm{B}}\right)$ sup E44 recA13 ara-14 leuB6 proA2 lacY1 rpsL20 $\left(\mathrm{Sm}^{\mathrm{r}}\right)$ xyl-5 mtl-1 & Boyer and Roulland-Dussoix 1969 \\
\hline HB101Rif & spontaneous Rif $^{\mathrm{r}}$ strain & Lab collection \\
\hline S $\phi 200$ Rif & metB strA purB $\Delta($ agg-uidA-man $) \mathrm{Rif}^{\mathrm{r}}$ & Wei et al. 2000 \\
\hline \multicolumn{3}{|c|}{ P. stewarti subsp. stewartiii } \\
\hline SS104 & Wild type, $\mathrm{Wts}^{+}, \mathrm{HR}^{+}$ & $\mathrm{ICPPB}^{\mathrm{a}}$ \\
\hline DC283 & $\mathrm{SS} 104 \mathrm{Nal}^{\mathrm{r}}$ & Coplin et al. 1986 \\
\hline DM064 & DC283 hrpY1296::Tn5 (Kan') & Frederick et al. 2001 \\
\hline DM701 & DC356 $\Delta h r p S$ hrpJ268::Tn3HoHoI $\left(\mathrm{Amp}^{\mathrm{r}}, \mathrm{Rif}^{\mathrm{r}}\right)$ & This study \\
\hline DM711 & DC283 hrpJ79::Tn3HoHoI $\left(\mathrm{Amp}^{\mathrm{r}}\right)$ & Frederick et al. 2001 \\
\hline DM729 & DC283 hrpY1296::Tn5 hrpJ79::Tn3HoHo $\left(\mathrm{Kan}^{\mathrm{r}}, \mathrm{Amp}^{\mathrm{r}}\right)$ & This study \\
\hline DM733 & DC283 hrpY64::Tn5 hrpS1::Tn3HoHoI (Kan $\left.{ }^{\mathrm{r}}, \mathrm{Amp}^{\mathrm{r}}\right)$ & This study \\
\hline DM758 & DC283 hrpS224::Tn5 (Kan $\left.{ }^{r}\right)$ & Frederick et al. 2001 \\
\hline DM786 & DC283 hrpJ79::Tn3HoHoI hrpL2560::aphA-3 (Kan $\left.{ }^{\mathrm{r}}, \mathrm{Amp}^{\mathrm{r}}\right)$ & This study \\
\hline DM2788 & DC283 $\Delta h r p X_{(17-470)}$ & This study \\
\hline DM2790 & DC283 $\Delta h r p X_{(17-414)}$ & This study \\
\hline DM2831 & DC283 hrpL-uidA (Tet') & This study \\
\hline DM2837 & DC283 hrpY hrpL-uidA $\left(\operatorname{Kan}^{\mathrm{r}} \operatorname{Tet}^{\mathrm{r}}, \mathrm{Tp}^{\mathrm{r}}\right)$ & This study \\
\hline DM2844 & DC283 hrpS hrpL-uidA $\left(\operatorname{Kan}^{\mathrm{r}}, \operatorname{Tet}^{\mathrm{r}}, \mathrm{Tp}^{\mathrm{r}}\right)$ & This study \\
\hline MEX1 & DC283 hrpS1::Tn3HoHoI (Amp $\left.{ }^{r}\right)$ & Frederick et al. 2001 \\
\hline MEX105 & DC283 hrpL105::Tn3HoHo $\left(\mathrm{Amp}^{\mathrm{r}}\right)$ & Frederick et al. 2001 \\
\hline MEX116 & DC283 hrpX1 16::Tn3HoHoI (Ampr) & Frederick et al. 2001 \\
\hline MM211 & DC283 hrp Y(D57A) & This study \\
\hline MM254 & DC283 hrpY(D57N) & This study \\
\hline \multirow{2}{*}{\multicolumn{3}{|c|}{$\begin{array}{l}\text { Plasmids } \\
\text { pBluescript }\end{array}$}} \\
\hline & & \\
\hline $\mathrm{KS}$ and SK $(+)$ & ColE1 alacZ $\left(\mathrm{Ap}^{\mathrm{r}}\right)$ & Stratagene \\
\hline pLAFR3 & IncP $\cos \operatorname{alac} Z\left(\mathrm{Tc}^{\mathrm{r}}\right)$ & Staskawicz et al. 1987 \\
\hline pRK415 & $\operatorname{IncP} \operatorname{alac} Z\left(\mathrm{Tc}^{\mathrm{r}}\right)$ & Keen et al. 1988 \\
\hline pVK100 & $\operatorname{IncP} \cos \left(\mathrm{Tc}^{\mathrm{r}}\right)$ & Knauf and Nester 1982 \\
\hline pLD55 & R6K ori, alacZ, tetAR $\left(\mathrm{Ap}^{\mathrm{r}}\right)$ & Metcalf et al. 1996 \\
\hline pUC18K & promoter/terminator-less aphA-3 cassette & Menard et al. 1993 \\
\hline pR751 & $\operatorname{IncP},\left(\mathrm{Tp}^{\mathrm{r}}, \mathrm{Sp} / \mathrm{Sm}^{\mathrm{r}}\right)$ & Ruvkun and and Ausubel 1981 \\
\hline pSU19 & pACYC187 replicon $\left(\mathrm{Cm}^{\mathrm{r}}\right)$ & Bartolome et al. 1991 \\
\hline pPL6GUSC & pLAFR6 derivative carrying a promoterless uidA gene $\left(\mathrm{Tc}^{\mathrm{r}}\right)$ & Knoop et al. 1991 \\
\hline pRK2013::Tn7 & ColE1 mob $^{+}$tra $_{\mathrm{RK} 2} \Delta$ rep $p_{\mathrm{RK} 2}$ repE kan::Tn7 $\left(\mathrm{Tp}^{\mathrm{r}}, \mathrm{Sm}^{\mathrm{r}}, \mathrm{Sp}^{\mathrm{r}}\right)$ & Ditta et al. 1980 \\
\hline pDM1296 & pES1044 hrp Y::Tn5 & Coplin et al. 1992 \\
\hline pDM2560 & pRF201 hrpL::aphA-3 & This study \\
\hline pDM2842 & pBKS (+) with PCR-made $h r p X$ allele deleted from aa 17 to 444 & This study \\
\hline pDM2846 & pBKS $(+)$ with PCR-made $h r p X$ allele deleted from aa 17 to 470 & This study \\
\hline pDM2848 & pLD55 with the $0.98-\mathrm{kb}$ Sst I-XhoI fragment from pDM2842 & This study \\
\hline pDM2851 & pLD55 with the 1.1-kb SstI-XhoI fragment from pDM2846 & This study \\
\hline pES1044 & cosmid clone in pVK100 containing left half of $h r p$ cluster & Coplin et al. 1986 \\
\hline pES411 & cosmid clone in pVK100 containing right half of $h r p$ cluster & Coplin et al. 1992 \\
\hline pMM6 & pRK415 with a 0.6-kb BamHI-EcoRI $h r p L^{+}$PCR fragment, transcribed from $\mathrm{P}_{l a c}$ & This study \\
\hline pMM22 & pBSK(+) with a 0.6-kb BamHI-EcoRI $h r p L^{+}$PCR fragment, transcribed from $\mathrm{P}_{l a c}$ & This study \\
\hline pMM46 & pBKS(+) with a $0.7-\mathrm{kb}$ HindIII $h r p Y$ fragment made by PCR, transcribed from $\mathrm{P}_{l a c}$ & This study \\
\hline pMM52 & pRK415 with the 0.7-kb BamHI-EcoRI $h r p Y^{+}$fragment from pMM46, transcribed from $\mathrm{P}_{l a c}$ & This study \\
\hline pMM57 & pBKS(+) with a $0.7-\mathrm{kb}$ HindIII $\operatorname{hrp} Y(\mathrm{D} 57 \mathrm{~A})$ fragment made by PCR-SOE & This study \\
\hline pMM58 & pRF201SK with the 1.7-kb HindIII fragment from pRF8 and containing $h r p L^{+}, h r p X Y^{+}, h r p S^{+}$ & This study \\
\hline pMM74 & pRK415 with the $0.7-\mathrm{kb}$ HindIII $h r p Y(\mathrm{D} 57 \mathrm{~A})$ fragment from pMM74, transcribed from $\mathrm{P}_{l a c}$ & This study \\
\hline pMM92 & pBKS(+) with a 0.7-kb HindIII $h r p Y(\mathrm{D} 57 \mathrm{~N})$ fragment made by PCR-SOE & This study \\
\hline pMM118 & pRK415 with a 0.7-kb HindIII $h r p Y(\mathrm{D} 57 \mathrm{~N})$ fragment from pMM92, transcribed from $\mathrm{P}_{l a c}$ & This study \\
\hline pMM245 & pLD55 with the $0.7-\mathrm{kb}$ SstI-XhoI fragment from pMM57 & This study \\
\hline pMM246 & pLD55 with the 0.7-kb SstI-XhoI fragment from pMM92 & This study \\
\hline pMM330 & pSU19 with the 0.7-kb SalI-SstI $h r p Y^{+}$fragment from pMM46, transcribed from $\mathrm{P}_{l a c}$ & This study \\
\hline pRF201 & $\begin{array}{l}\text { pLAFR3 with the 3.6-kb BamHI-HindIII fragment containing } h r p L^{+}, h r p X^{+} \text {and } h r p Y+\text { from } \\
\text { pES1044 }\end{array}$ & Coplin et al. 1992 \\
\hline pRF201SK & pBSK(+) with the 3.6-kb BamHI-HindIII fragment from pRF201 & This study \\
\hline pRF205 & pVK100 with the $1.7-\mathrm{kb}$ HindIII fragment containing hrpS from pES1044 & Frederick et al. 1993 \\
\hline pRF8 & pBSK(+) with the 1.7-kb HindIII fragment containing $h r p S$ from pRF205 & Frederick et al. 1993 \\
\hline pDM2531 & pPL6GUSC with a $0.9-\mathrm{kb}$ BamHI fragment to create a hrpJ-uidA fusion & This study \\
\hline pDM2785 & pPL6GUSC with a 389-bp BamHI PCR fragment to create a hrpL-uidA fusion & This study \\
\hline pDM2791 & pPL6GUSC with a 1.1-kb HindIII-BamHI fragment from pES411 to create a wtsE-uidA fusion & This study \\
\hline pMM25 & pPL6GUSC with a 244-bp HindIII-BamHI PCR fragment to create a $h r p X$-uidA fusion & This study \\
\hline pMM50 & pPL6GUSC with a 1.3-kb BamHI PCR fragment to create a $h r p S-u i d A$ fusion & This study \\
\hline
\end{tabular}

\footnotetext{
${ }^{a}$ International Collection of Plant Pathogenic Bacteria.
} 
null mutations and $l a c Z$ gene fusions were constructed by allele exchange of Tn5-mutagenized cosmids, as previously reported (Frederick et al. 2001), by using an incompatible plasmid, pR751 (Ruvkun and Ausubel 1981), to force the first cross-over event. Nonpolar hrpL mutations were constructed by ligating the $a p h A-3$ cassette from pUC18K (Menard et al. 1993) into $h r p L$ in pRF201. The resulting plasmid, pDM2560, was used to exchange the $h r p L:: a p h A-3$ allele into the Pantoea stewartii chromosome as described above. Several strategies to construct strains with usable chromosomal hrpL-lacZ transcriptional fusions were unsuccessful. Therefore, we created a strain with a single-copy chromosomal hrpL-uidA transcriptional fusion by a Campbell-type single crossover event. Plasmid pDM2785, which contains hrpLp cloned into pPL6GUSC, was forced to recombine with the hrpL locus on the chromosome, following introduction of an incompatible plasmid, pR751, to produce $h r p L$-uidA $h r p L^{+}, \operatorname{Tet}^{\mathrm{r}}$, and $\mathrm{Tp}^{\mathrm{r}}$ strains. This plasmid was recombined into wild-type (DC283), hrpY (DM064), and hrpS (DM758) backgrounds to produce strains DM2831, DM2837, and DM2844, respectively.

\section{Site-directed mutagenesis of $h r p Y$ codon D57 by overlap extension PCR and construction of missense mutant strains.}

To evaluate the role of the conserved aspartate residue at position 57 in HrpY, we performed site-directed mutagenesis by a modification of the megaprimer overlap extension PCR technique (Aiyar and Leis 1993). D57 was changed by nonconservative substitution to alanine (D57A) or by conservative substitution to asparagine (D57N). Five primers were designed: YFH and YRH delimited the hrpY ORF; YR2 was the antisense primer; and YD57N and YD57A were the sense-orientation mutagenic primers for each substitution. The mutagenic primers contained missense base changes at D57 (bold font in Table 3) and a near silent restriction site (NheI and DraI for YD57A and YD57N, respectively). PCRs were performed us- ing pMM46 as template DNA. The first round of reactions used primer pairs YFH+YR2 and YRH+YD57A (or YD57N) to produce 350- and 500-bp (or 508-bp) overlapping amplicons. Gel-purified PCR products from the two reactions were mixed, annealed, and used as templates for a second round of PCR, using primers YFH and YRH. PCR products were gelpurified and cloned into pBluescript $\mathrm{KS}(+)$. Recombinant colonies were screened by PCR and by restriction enzyme analysis for the presence of the marker restriction site, and the inserts were sequenced. Plasmids pMM57 and pMM92 contain the $\operatorname{hrp} Y(\mathrm{D} 57 \mathrm{~A})$ and $\operatorname{hrpY}(\mathrm{D} 57 \mathrm{~N})$ alleles, respectively. These inserts were then subcloned into pRK415 to produce plasmids pMM74 and pMM118, respectively. To construct missense $h r p Y$ mutants, the $h r p Y(D 57 A)$ and $h r p Y(D 57 N)$ ORFs were subcloned from pMM57 and pMM92 into suicide vector pLD55 (Metcalf et al. 1996) as XhoI/SstI inserts. The unmarked mutations were introduced into the Pantoea stewartii genome using the procedure described by Metcalf and associates (1996) and were confirmed by Southern blot hybridization.

\section{Construction \\ of Pantoea stewartii strains with in-frame deletions in hrpX.}

Two unmarked in-frame deletions in $h r p X$ were constructed in vitro by PCR. The deletions span amino acids 17 to 414 and 17 to 470 , as indicated in the subscripts. To construct $\Delta h r p X_{(17-414)}$, DNA fragments corresponding to the ends of $h r p X$ and its flanking sequences were amplified by PCR from cosmid pES1044, using primer pairs EdX1+BdX1 and BdX4+XdX3 (Table 3). $\Delta h r p X_{(17-470)}$ was similarly constructed using the same primers, except BdX3 was substituted for BdX4. PCR fragments were ligated into pBluescript $\mathrm{KS}(+)$ as EcoRIBam HI and BamHI-XbaI contiguous fragments. The deleted alleles were then ligated into pLD55 as XhoI/SstI inserts, transformed into E. coli BW20339 (Metcalf et al. 1996), mobilized to Pantoea stewartii, and introduced into the chromosome as described above. Cosmid pDM1296 hrpX $X^{+}$hrpY::Tn5, which

Table 3. Primers

\begin{tabular}{|c|c|c|c|}
\hline Primer & Sequence $\left(5^{\prime} \rightarrow 3^{\prime}\right)^{\mathrm{a}}$ & Sequence coordinates $\left(5^{\prime} \rightarrow 3^{\prime}\right)^{b}$ & Source \\
\hline \multicolumn{4}{|c|}{ pBluescript and pPL6GUSC vectors } \\
\hline $\mathrm{LacF}$ & ACCATGATTACGCCAAGCTC & 813-794 & This study \\
\hline LacR & GGCGATTAAGTTGGGTAACG & $577-558$ & This study \\
\hline $5 \mathrm{GUS}$ & CATTTCACGGGTTGGGGTTTCT & $15-36$ & Jefferson 1987 \\
\hline \multicolumn{4}{|c|}{ Pantoea stewartii subsp. stewartii } \\
\hline XFH & ACGGAAGCTTACTTCAAGGAGGCGAGATGC & 1364-1383 & This study \\
\hline $\mathrm{XRH}$ & ACGGAAGCTTGTCCTTCGCGCATGATGACG & 2924-2905 & This study \\
\hline YFH & CCGAAGCTTTTCGATAACAATATGGATAACAC & $2855-2877$ & This study \\
\hline YRH & CCGAAGCTTATTAAGAGCAATCCTAAGAGA & $3521-3501$ & This study \\
\hline LFB & CGCGGATCCACATTAAGCCAAACGGCAAAA & $662-642$ & This study \\
\hline LRE & CCGGAATTCTGTTTTACCCCGTTCAGTT & $1255-1237$ & This study \\
\hline 201.3 & CCTGGCGAACCTCATACAGG & $411-430$ & This study \\
\hline 201.1 & CGCTATCATCTCGCCCTGTG & $1691-1672$ & This study \\
\hline YD57A & TCTTTTACTGCTAGCTATGTGTATGCCTGG & $3022-3051$ & This study \\
\hline YD57N & CAGGTCGATCTTTTACTTTTAAATATGTGTATGCCTGG & 3014-3051 & This study \\
\hline YR2 & GTTTCAGGATCGTTATCTTTCGTGATG & $3204-3178$ & This study \\
\hline EdX1 & CGCGAATTCTTCGGTATTGCCCTGAACCT & 919-938 & This study \\
\hline $\mathrm{BdX} 1$ & CGCGGATCCTTTGATTGGCGTATCACTGCT & $1427-1407$ & This study \\
\hline $\mathrm{BdX} 2$ & CGCEGATCCAACGAGGTTCTCATAGAGGT & $2622-2641$ & This study \\
\hline BdX3 & CGCGGATCCACCAATGGAACCCGTGTGACT & $2794-2813$ & This study \\
\hline$X \mathrm{~d} X 3$ & CGCTCTAGATTTGCTCGGCGAGCATTTGG & $3272-3253$ & This study \\
\hline XFHG & 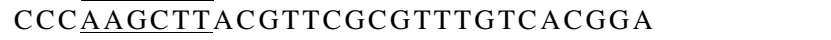 & $1182-1201$ & This study \\
\hline XRBG & CGCGGATCCTGATTGGCGTATCACTGCTA & $1425-1406$ & This study \\
\hline SFBG & 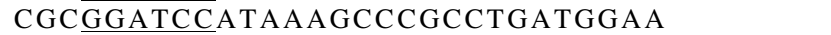 & $3423-3442$ & This study \\
\hline SR3BG & CGCGGATCCTCTAGATGGCATGCTATCGATCTCGT & $4735-4715$ & This study \\
\hline JFB G & 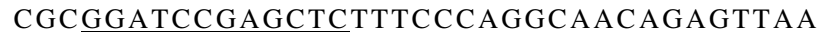 & $481-501$ & This study \\
\hline LRBG & 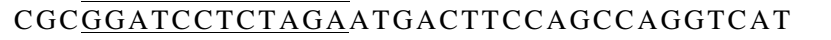 & $869-850$ & This study \\
\hline
\end{tabular}

${ }^{\mathrm{a}}$ Underlined bases represent engineered restriction sites; mutant codons are shown in bold character.

b Positions of LacF/R and 5GUS primers are according to GenBank accession X52331 (pBluescriptKS+) and U12639 (uidA locus), respectively; positions for Pantoea stewartii primers correspond to GenBank accession AF282857 and do not include the 5'-end restriction sites and anchoring tail. 
expresses $h r p X$ from its native promoter, restored HR elicitation to these mutants, thereby genetically confirming that these strains are, in fact, bona fide nonpolar $h r p X$ mutants.

\section{Construction of $\boldsymbol{h r p}$-promoter reporter plasmids.}

$h r p$ promoter fragments containing the $5^{\prime}$ regulatory regions of $h r p X, h r p S, h r p L, h r p J$, and wtsE were either produced by PCR, using the primers described in Table 3, or isolated as restriction fragments from cosmids pES411 or pES1044. To amplify the $h r p L$ promoter region from -207 to +182 (coordinates refer to the first base of the ORF), primers JFBG and LRBG were used (Table 3). An $h r p X$ promoter fragment containing from -198 to +46 bp was produced with primers XFHG and $\mathrm{XRBG}$. The hrpS promoter region from nucleotides -928 to +384 bp was amplified with primers SFG and SR3BG. To isolate two promoter regions containing $h r p$ boxes, a $0.9-\mathrm{kb}$ BamHI insert containing hrpJp and a 1.1-kb HindIII-BamHI fragment containing wtsEp were purified from plasmid pRF201::Tn5seq118 and cosmid pES411, respectively. The former plasmid has a Tn5seq insertion at +252 bp in hrpL ( $\mathrm{R}$. Frederick and D. Coplin, unpublished data). The DNA fragments, digested with BamHI, HindIII, or both as required were ligated into the low-copy, promoterless, uidA fusion vector pL6GUSC (Knoop et al. 1991). hrp-uidA reporter plasmids are listed in Table 2.

\section{Measurement of reporter gene activity.}

GUS activity was assayed fluorometrically using 4-methylumbelliferyl- $\beta$-D-glucuronide as described by Jefferson (1987), but the assays were scaled down to fit microtiter plates and were analyzed using a Victor 1420-2 multilabel reader (PEApplied Biosystems). Net GUS activity of each strain was corrected for the basal fluorescence of Pantoea stewartii DC283 or E. coli SФ200 carrying pL6GUSC without an insert. Specific activity was expressed in GUS units (pmol MU $\mathrm{min}^{-1}$ $\mathrm{OD}_{600}{ }^{-1} \mathrm{ml}^{-1}$ of culture at $37^{\circ} \mathrm{C}$ ). $\beta$-galactosidase ( $\beta$-Gal) activity was measured fluorometrically as described by Miller (1992) with the following modifications to adapt the protocol to the multiplate reader. Aliquots of cultures $(100 \mu \mathrm{l})$ were mixed with $100 \mu \mathrm{l}$ of a $2 \times \beta$-Gal assay buffer (2.5 mM 4methyl-umbelliferyl- $\beta$-D-galactopyranoside, $30 \%$ DMSO, and $200 \mathrm{mM} \mathrm{NaCl}$ in $200 \mathrm{mM}$ potassium phosphate buffer, $\mathrm{pH} \mathrm{7),}$ and data was collected as described above. $\beta$-Gal activity units were pmol MU $\min ^{-1} \mathrm{OD}_{600} \mathrm{~nm}^{-1} \mathrm{ml}^{-1}$ of culture at $25^{\circ} \mathrm{C}$.

\section{ACKNOWLEDGMENTS}

Salaries and research support were provided by research grants US2816-96 and US-3265-01C from the United States-Israel Binational Research and Development Fund and by state and federal funds appropriated to the Ohio Agricultural Research and Development Center, The Ohio State University. M. M. is supported by a Presidential Fellowship from The Ohio State University. Preliminary sequence data for $P$. syringae pv. tomato DC3000 was obtained from The Institute for Genomic Research website.

\section{LITERATURE CITED}

Ahmad, M., Majerczak, D. R., Pike, S., Hoyos, M. E., Novacky, A., and Coplin, D. L. 2001. Biological activity of harpin produced by Pantoea stewartii subsp. stewartii. Mol. Plant-Microbe Interact. 14:1223-1234.

Aiyar, A., and Leis, J. 1993. Modification of the megaprimer method of PCR mutagenesis: Improved amplification of the final product. Biotechniques 14:366-369.

Aldon, D., Brito, B., Boucher, C., and Genin, S. 2000. A bacterial sensor of plant cell contact controls the transcriptional induction of Ralstonia solanacearum pathogenicity genes. EMBO (Eur. Mol. Biol. Organ.) J. 19:2304-2314.

Alfano, J. R., and Collmer, A. 1997. The type (III Hrp) secretion pathway of plant pathogenic bacteria: Trafficking harpins, Avr proteins, and death. J. Bacteriol. 179:5655-5662.

Altschul, S. F., Madden, T. L., Schaffer, A. A., Zhang, J., Zhang, Z., Miller, W. et al. 1997. Gapped BLAST and PSI-BLAST: A new generation of protein database search programs. Nucleic Acids Res. 25:3389-3402.

Ausubel, F. M., Brent, R., Kingston, R. E., Moore, D. D., Seidman, J. G., Smith, J. A., and Struhl, K. (eds). 1987. Current Protocols in Molecular Biology, Vol. 1. New York: John Wiley \& Sons.

Bartolome, B. Y., Jubete, Y., Martinez, E., and de la Cruz, F. 1991. Construction and properties of a famility of pACYC184-derived cloning vectors compatible with pBR322 and its derivatives. Gene 102:75-78.

Boyer, H. W., and Roulland-Dussoix, D. 1969. A complementation analysis of the restriction and modification of DNA in Escherichia coli. J. Mol. Biol. 41:459-472.

Brito, B, Aldon, D., Barberis, P., Boucher, C., and Genin, S. 2002. A signal transfer system through three compartments transduces the plant cell contact-dependent signal controlling Ralstonia solanacearum hrp genes. Mol. Plant-Microbe Interact. 15:109-119.

Chatterjee, A., Cui, Y., and Chatterjee, A. K. 2002. Regulation of Erwinia carotovora $h r p L_{E C C}$ (sigma- $\mathrm{L}_{E C C}$ ), which encodes an extracytoplasmic function subfamily of sigma factor required for expression of the Hrp regulon. Mol. Plant-Microbe Interact. 15:971-980.

Claflin, L. E. 1999. Stewart's bacterial wilt. Pages 3-4 in: Compendium of Corn Diseases. White, D.G. (ed). American Phytopathological Society Press, St. Paul, MN, U.S.A.

Coplin, D. L., and Majerczak, D. R. 1990. Extracellular polysaccharide genes in Erwinia stewartii: Directed mutagenesis and complementation analysis. Mol. Plant-Microbe Interact. 3:286-292.

Coplin, D. L., Frederick, R. D., Majerczak, D. R., and Haas, E. S. 1986. Molecular cloning of virulence genes from Erwinia stewartii. J. Bacteriol. 168:619-623.

Coplin, D. L., Frederick, R. D., Majerczak, D. R., and Tuttle, L. D. 1992. Characterization of a gene cluster that specifies pathogenicity in $\mathrm{Er}$ winia stewartii. Mol. Plant-Microbe Interact. 5:81-88.

Ditta, G., Stanfield, S., Corbin, D., and Helinski, D. R. 1980. Broad host range DNA cloning system for gram-negative bacteria: Construction of a gene bank of Rhizobium meliloti. Proc. Natl. Acad. Sci. U.S.A. 77:7347-7351.

Dolph, P. J., Majerczak, D. R., and Coplin, D. L. 1988. Characterization of a gene cluster for exopolysaccharide biosynthesis and virulence in Erwinia stewartii. J. Bacteriol. 170:865-871.

Finlay, B. B., and Falkow, S. 1997. Common themes in microbial pathogenicity revisited. Microbiol. Mol. Biol. Rev. 61:136-169.

Frederick, R. D., Majerczak, D. R., and Coplin, D. L. 1993. Erwinia stewartii WtsA, a positive regulator of pathogenicity gene expression, is similar to Pseudomonas syringae pv. phaseolicola HrpS. Mol. Microbiol. 9:477-485.

Frederick, R. D., Ahmad, M., Majerczak, D. R., Arroyo-Rodriguez, A. S., Manulis, S., and Coplin, D. L. 2001. Genetic organization of the Pantoea stewartii subsp. stewartii hrp gene cluster and sequence analysis of the $h r p A, h r p C, h r p N$, and wtsE operons. Mol. Plant-Microbe Interact. 14:1213-1222.

Galan, J. E., and Collmer, A. 1999. Type III secretion machines: Bacterial devices for protein delivery into host cells. Science 284:1322-1328.

Goodrich, J. A., Schwartz, M. L., and McClure, W. R. 1990. Searching for and predicting the activity of sites for DNA binding proteins: Compilation and analysis of the binding sites for Escherichia coli integration host factor (IHF). Nucleic Acids Res. 18:4993-5000.

Hendrickson, E. L., Guevera, P., and Ausubel, F. M. 2000a. The alternative sigma factor RpoN is required for hrp activity in Pseudomonas sy ringae pv. maculicola and acts at the level of $h r p L$ transcription. J. Bacteriol. 182:3508-3516.

Hendrickson, E. L., Guevera, P., Penaloza-Vazquez, A., Shao, J., Bender, C., and Ausubel, F. M. 2000b. Virulence of the phytopathogen Pseudomonas syringae pv. maculicola is rpoN dependent. J. Bacteriol. 182:3498-3507.

Hoch, J. A., and Silhavy, T. J. (eds.) 1995. Two-Component Signal Transduction. American Society for Microbiology, Washington, DC.

Hutcheson, S. W., Bretz, J., Sussan, T., Jin, S., and Pak, K. 2001. Enhancer-binding proteins HrpR and HrpS interact to regulate hrp-encoded type III protein secretion in Pseudomonas syringae strains. J. Bacteriol. 183:5589-5598.

Inoue, H., Nojima, H., and Okayama, H. 1990. High efficiency transformation of Escherichia coli with plasmids. Gene 96:23-28.

Jefferson, R. A. 1987. Assaying chimeric genes in plants: The GUS gene fusion system. Plant Mol. Biol. Rep. 5:387-405.

Jin, S. G., Prusti, R. K., Roitsch, T., Ankenbauer, R. G., and Nester, E. W. 1990. Phosphorylation of the VirG protein of Agrobacterium tumefaciens by the autophosphorylated VirA protein: Essential role in biological activity of VirG. J. Bacteriol. 172:4945-4950. 
Kadner, R. J. 1995. Expression of the Uhp sugar phosphate transport system of Escherichia coli. Pages 263-274 in: Two-Component Signal Transduction. J. A. Hoch, and T. J. Silhavy, (eds.) American Society for Microbiology, Washington, DC.

Keen, N. T., Tamaki, S., Kobayashi, D., and Trollinger, D. 1988. Improved broad-host-range plasmids for DNA cloning in gram-negative bacteria. Gene 70:191-197.

Klement, Z. 1982. Hypersensitivity. Pages 150-178 in: Phytopathogenic Prokaryotes. Vol.1. M. S. Mount, and G. S. Lacy, eds. Academic Press, New York.

Knauf, V. C., and Nester, E. W. 1982. Wide host range cloning vectors: A cosmid clone bank of an Agrobacterium Ti plasmid. Plasmid 8:45-54.

Knoop, V., Staskawicz, B., and Bonas, U. 1991. Expression of the avirulence gene avrBs3 from Xanthomonas campestris pv. vesicatoria is not under the control of hrp genes and is independent of plant factors. J. Bacteriol. 173:7142-7150.

Lindgren P. B. 1997. The role of hrp genes during plant-bacterial interactions. Annu. Rev. Phytopathol. 35:129-152.

Lonetto, M. A., Brown, K. L., Rudd, K. E., and Buttner, M. J. 1994 Analysis of the Streptomyces coelicolor sigE gene reveals the existence of a subfamily of eubacterial RNA polymerase sigma factors involved in the regulation of extracytoplasmic functions. Proc. Natl. Acad. Sci. U.S.A. 91:7573-7577.

Marchler-Bauer, A., Panchenko, A. R., Shoemaker, B. A., Thiessen, P. A. Geer, L. Y., and Bryant, S. H. 2002. CDD: A database of conserved domain alignments with links to domain three-dimensional structure. Nucleic Acids Res. 30:281-283.

McCleary, W. R., Stock, J. B., and Ninfa, A. J. 1993. Is acetyl phosphate a global signal in Escherichia coli? J. Bacteriol. 175:2793-2798.

Menard, R., Sansonetti, P. J., and Parsot, C. 1993. Nonpolar mutagenesis of the ipa genes defines IpaB, IpaC, and IpaD as effectors of Shigella flexneri entry into epithelial cells. J. Bacteriol. 175:5899-5906.

Metcalf, W. W., Jiang, W., Daniels, L. L., Kim, S. K., Haldimann, A., and Wanner, B. L. 1996. Conditionally replicative and conjugative plasmids carrying lacZ $\alpha$ for cloning, mutagenesis, and allele replacement in bacteria. Plasmid 35:1-13.

Miller, J. H. 1992. A short course in bacterial genetics: A laboratory manual and handbook for Escherichia coli and related bacteria. Cold Spring Harbor Laboratory Press, Cold Spring Harbor, NY, U.S.A.

Moore, J. B., Shiau, S. P., and Reitzer, L. J. 1993. Alterations of highly conserved residues in the regulatory domain of nitrogen regulator I (NtrC) of Escherichia coli. J. Bacteriol. 175:2692-2701.

Mor, H., Manulis, S., Zuck, M., Nizan, R., Coplin, D. L., and Barash, I. 2001. Genetic organization of the hrp gene cluster and $d s p A E / B F$ operon in Erwinia herbicola pv. gypsophilae. Mol. Plant-Microbe Interact. 14:431-436.

Nizan-Koren, R., Manulis, S., Mor, H., Iraki, N.M., and Barash, I. 2003. The regulatory cascade that activates the Hrp regulon in Erwinia herbicola pv. gypsophilae. Mol. Plant-Microbe Interact 16:249-260.

Poetter, K., and Coplin, D. L. 1991. Structural and functional analysis of the rcsA gene from Erwinia stewartii. Mol. Gen. Genet. 229:155-160.

Porter, S. C., North, A. K., and Kustu, S. 1995. Mechanism of transcriptional activation by NtrC. Pages 147-158 in: Two-Component Signal Transduction. J.A. Hoch and T. J. Silhavy, eds. American Society for Microbiology Press, Washington, D.C., U.S.A.

Rahme, L. G., Mindrinos, M. N., and Panopoulos, N. J. 1991. Genetic and transcriptional organization of the hrp cluster of Pseudomonas syringae pv. phaseolicola. J. Bacteriol. 173:575-586.

Rahme, L. G., Mindrinos, M. N., and Panopoulos, N. J. 1992. Plant and environmental sensory signals control the expression of hrp genes in
Pseudomonas syringae pv. phaseolicola. J. Bacteriol. 174:3499-3507.

Reese, M. G., Harris, N. L., and Eckman, F. H. 1996. Large scale sequencing specific neural networks for promoter and splice site recognition. In: Biocomputing: Proceedings of the 1996 Pacific Symposium. L. Hunter and T. E. Klein, eds. World Scientific Publishing Co. Singapore.

Ruvkun, G. B., and Ausubel, F. M. 1981. A general method for site-directed mutagenesis in prokaryotes. Nature 289:85-88.

Schulte, R., and Bonas, U. 1992. Expression of the Xanthomonas campestris pv. vesicatoria hrp gene cluster, which determines pathogenicity and hypersensitivity on pepper and tomato, is plant inducible. J. Bacteriol. 174:815-823.

Shattuck-Eidens, D. M., and Kadner, R. J. 1983. Molecular cloning of the uph region and evidence for a positive activator for expression of the hexose phosphate transport system of Escherichia coli. J. Bacteriol. 155:1060-1070.

Staskawicz, B., Dahlbeck, D., Keen, N., and Napoli, C. 1987. Molecular characterization of cloned avirulence genes from race 0 and race 1 of Pseudomonas syringae pv. glycinea. J. Bacteriol. 169:5789-5794.

Stephenson, K., and Hoch, J. A. 2001. PAS-A domain of phosphorelay sensor kinase A: A catalytic ATP-binding domain involved in the initiation of development in Bacillus subtilis. Proc. Natl. Acad. Sci. U.S.A. 98:15251-15256.

Taylor, B. L., and Zhulin, I. B. 1999. PAS domains: Internal sensors of oxygen, redox potential, and light. Microbiol. Mol. Biol. Review. 63:479-506.

Torres-Cabassa, A., Gottesman, S., Frederick, R. D., Dolph, P. J., and Coplin, D. L. 1987. Control of extracellular polysaccharide synthesis in Erwinia stewartii and Escherichia coli K-12: A common regulatory function. J. Bacteriol. 169:4525-4531

Wei, Z. M., and Beer, S. V. 1995. hrpL activates Erwinia amylovora hrp gene transcription and is a member of the ECF subfamily of sigma factors. J. Bacteriol. 177:6201-6210.

Wei, Z. M., Sneath, B. J., and Beer, S. V. 1992. Expression of Erwinia amylovora $h r p$ genes in response to environmental stimuli. J. Bacteriol. 174:1875-1882.

Wei, Z., Kim, J. F., and Beer, S. V. 2000. Regulation of hrp genes and type III protein secretion in Erwinia amylovora by HrpX/HrpY, a novel two-component system, and HrpS. Mol. Plant-Microbe Interact. 13:1251-1262.

Xiao, Y., and Hutcheson, S. W. 1994. A single promoter sequence recognized by a newly identified alternate sigma factor directs expression of pathogenicity and host range determinants in Pseudomonas syringae. J. Bacteriol. 176:3089-3091.

Xiao, Y., Lu, Y., Heu, S., and Hutcheson, S. W. 1992. Organization and environmental regulation of the Pseudomonas syringae pv. syringae 61 hrp cluster. J. Bacteriol. 174:1734-1741.

Xiao, Y., Heu, S., Yi, J., Lu, Y., and Hutcheson, S. W. 1994. Identification of a putative alternate sigma factor and characterization of a multicomponent regulatory cascade controlling the expression of Pseudomonas syringae pv. syringae Pss61 hrp and hrmA genes. J. Bacteriol. 176:1025-1036.

\section{AUTHOR-RECOMMENDED INTERNET RESOURCES}

The National Center for Biotechnology Information: www.ncbi.nlm.nih.gov. The Institute for Genomic Research website: www.tigr.org.

The Berkeley Drosophila Genome Project: www.fruitfly.org/seq_tools/ promoter.html 